\section{FedUni ResearchOnline}

\section{https://researchonline.federation.edu.au}

Copyright Notice

This is the published version of:

Drake, B., Koroznikova, L., Tuck, M., \& Durkin, S. (2019). Application of Thermal Fragmentation in Australian Hard Rock Underground Narrow-Vein Mining. Mining, Metallurgy and Exploration. https://doi.org/10.1007/s42461-019-00154-z

Available online at https://doi.org/10.1007/s42461-019-00154-z

Copyright $\odot 2019$ Drake et al. This is an open-access article distributed under the terms of the Creative Commons Attribution License (CC BY 4.0) (http://creativecommons.org/licenses/by/4.0/). The use, distribution or reproduction in other forums is permitted, provided the original author(s) or licensor are credited and that the original publication in this journal is cited, in accordance with accepted academic practice. No use, distribution or reproduction is permitted which does not comply with these terms. 


\title{
Application of Thermal Fragmentation in Australian Hard Rock Underground Narrow-Vein Mining
}

\author{
Bradley Drake ${ }^{1} \cdot$ Larissa Koroznikova $^{1} \cdot$ Michael Tuck $^{1}$ (D) $\cdot$ Steve Durkin ${ }^{2}$ \\ Received: 31 March 2019 / Accepted: 7 November 2019 / Published online: 1 December 2019 \\ (C) Society for Mining, Metallurgy \& Exploration Inc. 2019
}

\begin{abstract}
This paper presents the results from the investigation of the application of thermal fragmentation in Australian hard rock underground narrow-vein mining. Two geologically similar samples from an underground narrow-vein hard rock gold mine were collected to obtain a measure of the technology's ability to recover ore by the creation of large thermal openings to assess the applicability of the thermal method. Particle size distribution showed a higher generation of fine product, $-2 \mathrm{~mm}$, by thermal fragmentation compared with selective blasting by $31 \%$. The Bond work index for thermal ore $(12.62 \mathrm{kWh} / \mathrm{t})$ is half to that of the blasted ore value $(25.32 \mathrm{kWh} / \mathrm{t})$. The average grindability obtained for the thermal ore sample was greater than the blasted sample by a factor of 2.44 , a higher value indicating a decrease in the energy required to grind. The thermal fragmentation method generates product with higher dissolution of gold in cyanide, by $14 \%$ for the $-9.5+2 \mathrm{~mm}$ size fraction samples. Additionally, the thermal fragmentation results in higher production of $-9.5+2 \mathrm{~mm}$ material by $15 \%$ compared with selective blasting.
\end{abstract}

Keywords Underground mining $\cdot$ Gold $\cdot$ Narrow vein $\cdot$ Fragmentation

\section{Introduction}

The profitable extraction of valuable minerals from orebodies forms the main objective of any mining enterprise. Both, open pit and underground, minings are profitable only when the revenue exceeds the costs of extraction and refinement of a saleable product.

Narrow-vein type deposits are particularly challenging to mine profitably. A definition of a narrow-vein deposit is an orebody less than $3 \mathrm{~m}$ average thickness. Narrow-vein systems have historically represented an important source of the world's exploitable gold, silver, tin and uranium [7], but have proven problematic to mining companies due to the complexities inherent to these deposits. These complexities include but are not limited to their predisposition to erratic grades, often attributed to the nuggetty distribution of gold throughout the system and its complex geology, resulting in difficulty of estimating resources [8].

Michael Tuck

m.tuck@federation.edu.au

1 Federation University Australia, Ballarat, Australia

2 Safescape, Golden Gully, Australia
These complications result in narrow-vein systems being high-risk investments and as such, it tends to be difficult to raise funding for both exploration and exploitation of these deposits. Narrow-vein systems are generally low tonnage and expensive to mine, mainly due to the work force requirements during both the development and production cycles of mining [9]. Additionally, conventional extraction methods often result in significant dilution of the ore, and there are substantial limitations pertaining to the mechanisation of the extraction process. The costs associated with the development of narrow-vein deposits is largely similar to those of a bulk mining operation, but as these costs are distributed over lower tonnes at variable grades [9], the extraction of the targeted material must be economical or beneficial to the overall mining operation.

Mining operations in most instances consist of two distinct subsystems, the mine and the processing plant. The focus of significant work in the field of mine-to-mill optimisation [10, $17,18]$ is the adjustment of one or both subsystems in order to obtain an optimum set of variables for the overall mining operation. A suggested approach to achieving this optimisation is improvement of the blasted fragmentation of the run of mine ore rock. The goal is to produce a fragment size distribution that would minimise overall mining and processing costs [17]. 
The processing plant consumes a large portion of the energy supplied to a mine site. When processes in the plant include crushing, grinding, flotation, concentration and leaching of the ore, that portion can increase to approximately $82 \%$ of total energy requirements [16]. In most instances, comminution circuits account for the greatest fraction of expended energy in the processing plant and can range from 30 up to $73.5 \%$ [11, 21]. A reduction in the costs of comminution would therefore be an important step to produce savings for a mining operation. These potential saving (Table 1) values will vary depending on the hardness of the ore as well as the grain size characteristics [21].

Therefore, in order to achieve an energy efficient operation; firstly, production of fine material during blasting or during the primary breakage method should be maximised, and secondly, a reduction of the quantity of processed tonnes required to produce a final product would prove to be economical.

Generation of a relatively fine primary mining product is achieved by high intensity blasting, employing the low cost energy of explosives. High intensity blasts, when effectively controlled, transmit a large fraction of the useful energy into the particle size reduction of the blasted rock.

The difficulty encountered when increasing the explosive energy in a confined area, such as a narrow vein of ore, is that the transfer of the energy contained in the explosive to the target material is not $100 \%$ efficient. This excess explosive energy can result in breakage of the surrounding wallrock, adding additional tonnes that dilute the ore sent to the mill and can destabilise the working area, consequently increasing the costs of ground support. Minimising the tonnes processed to provide an economic final product requires a high level of selectivity in mining.

\subsection{Thermal Fragmentation}

The fragmentation method proposed in this study consists of a strong burner (Fig. 1) powered by diesel fuel and compressed air of approximately $115 \mathrm{~mm}$ diameter. The process involves inserting the burner into a $152 \mathrm{~mm}$ diameter pilot hole, drilled by a longhole drill. The burner is located at the toe end of the hole and is ignited. The in-hole temperature can rise up to 800 ${ }^{\circ} \mathrm{C}$, and this thermal stress creates a spalling effect [15], causing individual grains within the rock on the outermost surface of the drillhole to expand and contract depending on their own inherent thermal expansion factors. When the thermal expansions of adjacent grains in a rock vary sufficiently, intergranular fracture occurs; reducing particle cohesion and the subjected particles tear away from the coherent wallrock [5]. This spalling allows for the expansion of the pilot hole cavity, increasing the diameter of the hole from the drilled from $152 \mathrm{~mm}$ to a maximum of $1200 \mathrm{~mm}$ by the simple action of leaving the burner in a particular part of the hole for a given duration of time. The durations vary depending on the geology of the rock and are site specific. Narrow excavations of 250-450 $\mathrm{mm}$ require short residence time of 5-10 $\mathrm{min}$, and larger excavations require up to $15-25 \mathrm{~min}$. Once the time has elapsed, the burner head is retreated out of the opening for about $600-900 \mathrm{~mm}$ to continue the thermal process on the next slice of the vein (Note: These are approximations based on the use of thermal unit in an underground Australian hard rock mine). The process continues until the burner head becomes proximate to the collar of the pilot hole, and then the thermal unit moves to its next hole.

The rock fragments produced are removed by a vacuum. This vacuum system creates a pressure seal around the collar of the pilot hole, removing both fragments of rock and any exhaust fumes from the burner, ensuring no fumes or gases are vented into the working area.

The process produces fragments of $<13 \mathrm{~mm}$ in size which are transported by means of the vacuum system to a stockpile for loading or directly to a haulage vehicle. The product size of thermal fragmentation largely eliminates the need for primary crushing (Fig. 2), producing a material more suited for fine grinding.

During vacuuming of the hole, the particles are injected with a stream of water to prevent the overheating of the transmission pipes by the quenching of the heated ore; this also aids the transmission by fluidising the ore.

\subsection{Applications of Thermal Fragmentation}

In underground mining, a considerable interest exists in nonblasting methods of extraction, especially in built-up areas such as those in the Victorian goldfields in Australia [14]. In respect to the underground mining of narrow veins in hard rock, thermal fragmentation provides a degree of competition to the methods generally relied on for the extraction of ore, such as longhole open stoping, shrinkage stoping, cut-and-fill and resue mining.
Table 1 Relative energy and cost of breakage [18].

\begin{tabular}{lllll}
\hline 12 breakage mechanism & $\begin{array}{l}\text { Energy }(\mathrm{kWt} / \\
\mathrm{t})\end{array}$ & Energy multiplying factor & Cost $(\$ / \mathrm{t})$ & Cost multiplying factor \\
\hline Blasting & 0.2 & 1 & 0.15 & 1 \\
Crushing & 2 & 10 & 0.75 & 5 \\
Grinding & 20 & 100 & 3.75 & 25 \\
\hline
\end{tabular}


Fig. 1. a Thermal fragmentation burner head [15]. b thermal burner flame [4]

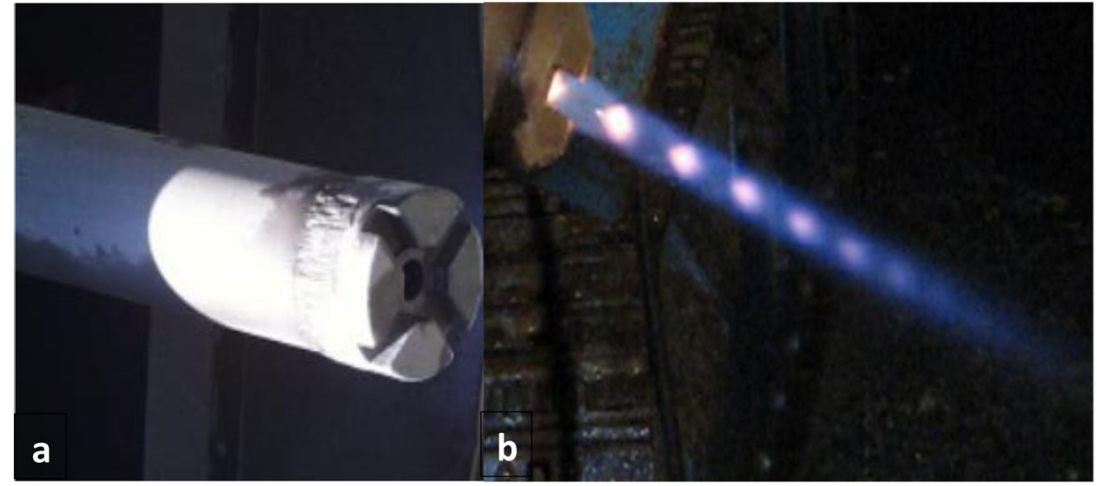

Longhole open stoping is suited for the extraction of steeply dipping veins of width exceeding $1.5 \mathrm{~m}$ and provided the continuity is substantial, could prove more practical option to mine a deposit of this nature [12].

Shrinkage stoping is suited to deposits steeply dipping and of width less than $1.5 \mathrm{~m}$. Dilution, safety and manpower become variables worth consideration when deciding the application of this method. Blasting breaks the rock and this encourages dilution of the ore. Drilling of blastholes for this method often is completed from the top of previously broken ore by pneumatic airleg drill. Skilled manpower is a vital component of this method, airleg operation is a strenuous job, which is generally done from on top of an unconsolidated ore rock pile. This method presents some safety risk, and the requirement for skilled labour accounts for up to $40 \%$ of the costs of mining [7].

A benefit of the application of thermal fragmentation on a vein of the same characteristics is a two-man crew that is required for the operation of the thermal unit, and the fragmented ore is largely removed from the hole during operation. Drilling of pilot holes for thermal fragmentation constitutes the only additional requirement for manpower during mining.

For resue mining and cut-and-fill mining, controlled blasting practices could be utilised to minimise dilution; delays in the mining cycle will be encountered during both the

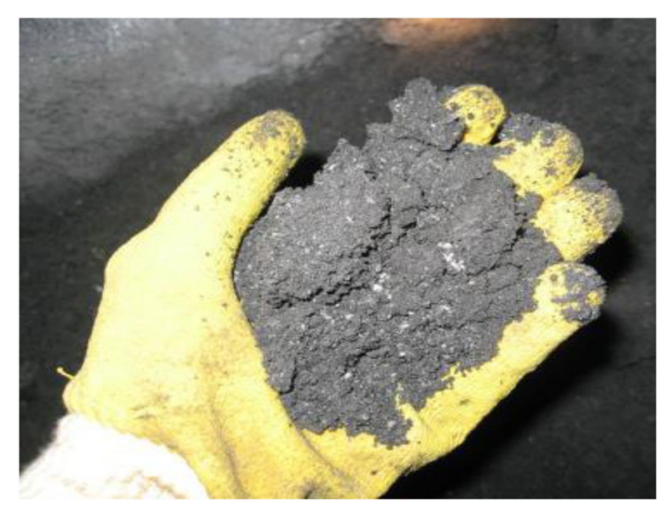

Fig 2. Thermally fragmented rock [4] split face firing of the waste and ore and whilst filling during cut-and-fill mining. Increased cycle time often results in losses in production and therefore profit. Due to this, alternative methods may be sought to extract the ore without delays.

Utilisation of thermal drilling may prove more economical for the extraction of the narrow vein of ore. The high selectivity of the method in consort with the production of a primary mining product of reduced size would result in mitigated haulage costs and decrease the volume of ore requiring crushing. Any assessment of the viability of this process must also take into account the increase cost per tonne inherent to thermal fragmentation.

A cost comparison was completed by Rocmec International Inc., between longhole open stoping and thermal fragmentation (Table 2) [15]. From the table, the unit cost $\$ 113.50 / \mathrm{t}$ for thermal fragmentation is significantly greater than $\$ 19.50 /$ t for longhole open stoping. The example takes into account the substantial difference in dilution between the processes, resulting in the extraction of 12,645 tonnes of additional reserves in the longhole method to produce a similar number of ounces.

Table 3 illustrates the significance of extracting only profitable material during a mining operation. The estimated thermal fragmentation unit mining cost per tonne is 6 times greater than that of the longhole method, but in this example, the thermal process produces an ounce of gold at a discounted rate and therefore generates a greater profit margin.

Comminution benefits accrue from treating rock fragmented by thermal stress due to a reduction of both feed tonnage and particle size of the feed for further processing. Reduced run of mine (ROM) tonnage to the mill decreases energy requirements and results in reduced wear on the comminution equipment. With the production of a finer primary mining product, elimination or substantial reduction of the existing initial coarse stage of particle size reduction can be realised. Overall comminution energy savings are then realised as defined in a study concerning fine grinding in respect to a decrease in grinding feed size [21].

The substantial thermal stress applied during the process is analogous to thermal preconditioning that has been 
Table2 Theoretical cost comparison between thermal fragmentation and longhole open stoping [15]

\begin{tabular}{|c|c|c|c|c|}
\hline $\begin{array}{l}\text { Tonnage calculated on the basis of a } 60 \mathrm{~m} \text { by } \\
60 \mathrm{~m} \text { reserve block }\end{array}$ & \multicolumn{2}{|c|}{ Thermal drilling $2024 \mathrm{t}$} & \multicolumn{2}{|c|}{ Longhole drilling $3024 \mathrm{t}$} \\
\hline Grade in situ $(g / t)$ & \multicolumn{2}{|l|}{35} & \multicolumn{2}{|l|}{35} \\
\hline Width in situ $(\mathrm{cm})$ & \multicolumn{2}{|l|}{30} & \multicolumn{2}{|l|}{30} \\
\hline Minimum width (cm) & \multicolumn{2}{|l|}{30} & \multicolumn{2}{|l|}{140} \\
\hline Dilution & \multicolumn{2}{|l|}{0} & \multicolumn{2}{|l|}{367} \\
\hline Geological reserves $(\mathrm{t})$ & \multicolumn{2}{|l|}{3024} & \multicolumn{2}{|l|}{14,112} \\
\hline Reserve grade $(g / t)$ & \multicolumn{2}{|l|}{35} & \multicolumn{2}{|l|}{7.5} \\
\hline \multicolumn{5}{|l|}{ Mining } \\
\hline Wall dilution (\%) & \multicolumn{2}{|l|}{5} & \multicolumn{2}{|l|}{35} \\
\hline Stope recovery $(\%)$ & \multicolumn{2}{|l|}{79} & \multicolumn{2}{|l|}{90} \\
\hline Ore development $(\mathrm{t})$ & \multicolumn{2}{|l|}{544} & \multicolumn{2}{|l|}{2540} \\
\hline Planned mining reserves $(\mathrm{t})$ & \multicolumn{2}{|l|}{1961} & \multicolumn{2}{|l|}{14,606} \\
\hline Grade $(g / t)$ & \multicolumn{2}{|l|}{33.25} & \multicolumn{2}{|l|}{4.88} \\
\hline Mill recovery $(\%)$ & \multicolumn{2}{|l|}{96} & \multicolumn{2}{|l|}{96} \\
\hline \multirow[t]{3}{*}{ Produced ounces } & \multicolumn{2}{|l|}{2013} & \multicolumn{2}{|l|}{2198} \\
\hline & \multicolumn{2}{|c|}{ Thermal drilling } & Longhole $\mathrm{d}$ & \\
\hline & $\begin{array}{l}\text { Unit cost } \\
\text { CAD } / \mathrm{m}\end{array}$ & $\begin{array}{l}\text { Total cost } \\
\mathrm{CAD} / \mathrm{m}\end{array}$ & $\begin{array}{l}\text { Unit cost } \\
\qquad \mathrm{CAD} / \mathrm{m}\end{array}$ & $\begin{array}{l}\text { Total cost } \\
\mathrm{CAD} / \mathrm{m}\end{array}$ \\
\hline Development & & & & \\
\hline Drifts & 1000.00 & $180,000.00$ & 1000.00 & $180,000.00$ \\
\hline Subdrifts & 1000.00 & $120,000.00$ & 1000.00 & $120,000.00$ \\
\hline Raises & 1000.00 & $60,000.00$ & 1000.00 & $120,000.00$ \\
\hline Drawpoint & 1000.00 & & 1000.00 & $60,000.00$ \\
\hline Mining cost $(\mathrm{C} \$ / \mathrm{t})$ & 113.50 & $222,600.00$ & 19.00 & $277,516.00$ \\
\hline Mucking & 8.00 & $15,690.00$ & 4.00 & $58,424.00$ \\
\hline Transportation & 12.00 & $23,535.00$ & 6.00 & $87,636.00$ \\
\hline Milling & 16.00 & $31,380.00$ & 20.00 & $292,122.00$ \\
\hline Environment & 2.00 & 3922.00 & 2.00 & $29,212.00$ \\
\hline Backfilling & & & 5.00 & $73,030.00$ \\
\hline Total & & $657,127.00$ & & $1,297,940.00$ \\
\hline $\mathrm{C} \$$ per tonne & & 335.06 & & 88.86 \\
\hline $\mathrm{C} \$$ per ounce & & 326.49 & & 590.59 \\
\hline US\$ per ounce (rate 0.65 ) & & 212.22 & & 383.88 \\
\hline
\end{tabular}

investigated since the 1920s. Such studies were summarised by Tavares \& King; they concluded that improvements to the efficacy of the comminution circuit existed when a mill feed material is subjected to a sufficient degree of thermal preconditioning.

Table 3 Thermal and longhole profit estimation. Note: Profit based on mean gold price of US\$1200/oz (Jan. 17)

\begin{tabular}{lll}
\hline & Thermal & Longhole \\
\hline Cost per ounce (US\$) & 212.22 & 383.88 \\
Profit per ounce (US\$/oz) & 987.78 & 816.12 \\
Total profit (US\$) & 1.988 million & 1.793 million \\
\hline
\end{tabular}

The effect of thermal pre-treatment of brittle material on the breakage characteristics of a treated rock is attributed to the differential thermal expansion of adjacent grains, is not associated with the rate of heating and is independent of the number of heating cycles applied [5], merely due to the temperature of thermal expansion. During experimentation, Brown, Gaudin and Loeb Jr found that heat treatments up to $700{ }^{\circ} \mathrm{C}$ have varied levels of effect on the breakage characteristics of samples of granite, and that further increases in temperature up to $1000{ }^{\circ} \mathrm{C}$ had a limited effect [6]. Heat treatment of quartz samples by Tavares and King followed by subsequent water quenching showed a reduction; the required energy for fracture by at least $55 \%$ in the particle size interval of $0.7-5 \mathrm{~mm}$. This effect, caused by the heat treatment and quenching, was enhanced in the finer particles [19]. Given that the thermal fragmentation process incorporates quenching of the 
Fig 3 Particle size distributions for samples generated by thermal fragmentation and blasted rock

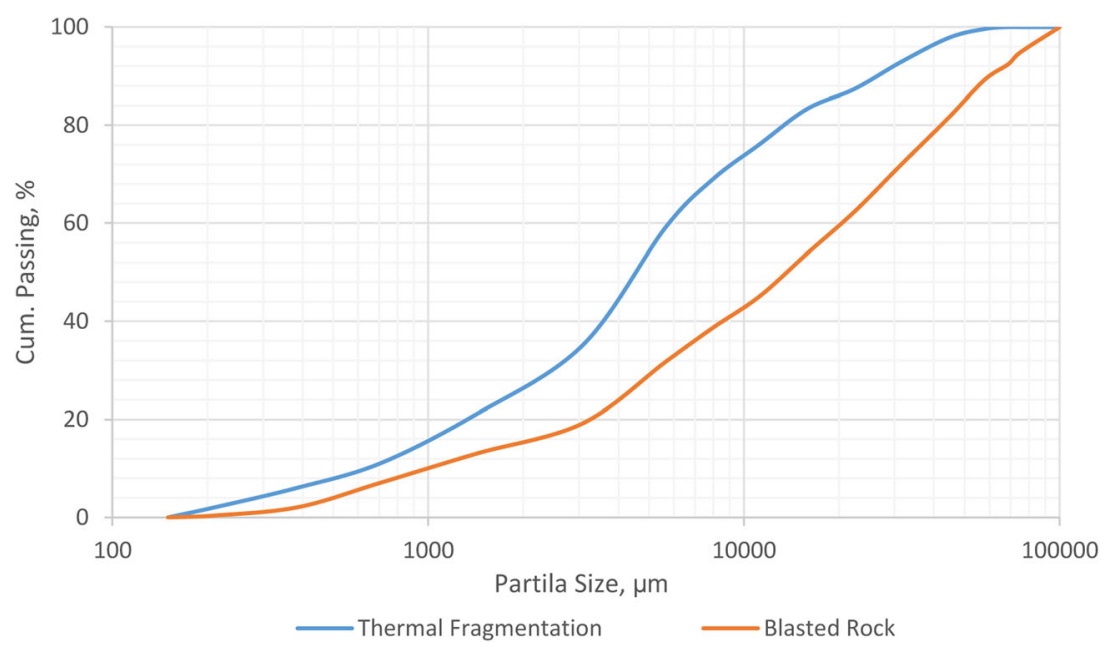

vacuumed fragments, a degree of this effect may occur and thus increase the efficacy of comminution.

As the thermal fragmentation breakage mechanism involves differential expansion of adjacent grains of the rock structure, applying the process to structures containing minerals of different composition (e.g. quartz and gold) could elicit liberation of the gold. Because liberation of the valuable component of the ore from the gangue is the objective of size reduction operations [6], thermal fragmentation may provide additional opportunity for energy savings in the processing plant. If a liberation effect eventuates from the thermal stress, ultra-fine grinding could be reduced if not eliminated from the treatment process.

Thermal fragmentation technology has been employed in a number of countries since its conception and consequent development into a viable narrow-vein mining method. During the period of 2009-2010 [1-3], thermal fragmentation technology was deployed at Great Basin Gold's Hollister mine, NV, USA; Newmont's Midas mine, NV, USA and Fresnillo La Cienega mine, Mexico. In 2014, exclusive distributorship agreements were established with Maxem Holdings for South Africa and NDR for distribution of the technology in Japan.

\section{Experimental}

\subsection{Material}

In order to incorporate the thermal fragmentation into Australian mining operations, a series of tests were undertaken

Table 4 Sample retained mass comparison

\begin{tabular}{lll}
\hline Size fraction $(\mathrm{mm})$ & $\begin{array}{l}\text { Thermal ore } \\
\text { Retained }(\%)\end{array}$ & Blasted ore \\
\hline+9.5 & 23.9 & 54.9 \\
$-9.5+2$ & 41.0 & 25.9 \\
-2 & 35.1 & 19.2 \\
\hline
\end{tabular}

to demonstrate the process and to test the performance of the new technology under Australian mining conditions by Safescape, a mining contracting company.

One of the trials took place in an underground narrow-vein hard rock gold mine, approximately $50 \mathrm{~km}$ northeast of Melbourne. A number of pilot holes were drilled, both directly into the gold bearing quartz veins and into the host rock to obtain a measure of the technology's ability to create large thermal openings for assessing the applicability of the thermal method in creating the excavations required for the installation of their laddertube systems.

Two economical grade gold ore samples were collected to perform assessment and comparison of the products generated using the two approaches. One sample, thermally fragmented

Table 5 Sample retained mass comparison

\begin{tabular}{lll}
\hline Screen Size $(\mu \mathrm{m})$ & $\begin{array}{l}\text { Thermal ore } \\
\text { Retained }(\%)\end{array}$ & Blasted ore \\
\hline$+75,000$ & 0.00 & 5.17 \\
$75,000+63,000$ & 0.00 & 2.39 \\
$63,000+53,000$ & 0.43 & 3.19 \\
$53,000+37,500$ & 1.79 & 7.64 \\
$37,500+26,500$ & 4.91 & 9.61 \\
$26,500+19,000$ & 5.43 & 9.61 \\
$19,000+13,200$ & 4.16 & 8.60 \\
$-13,200+9500$ & 7.14 & 8.70 \\
$-9500+6700$ & 7.13 & 6.43 \\
$-6700+4750$ & 9.91 & 6.96 \\
$-4750+2000$ & 23.96 & 12.50 \\
$-2000+1000$ & 14.11 & 6.19 \\
$-1000+500$ & 9.89 & 5.94 \\
$-500+300$ & 5.09 & 4.97 \\
$-300+150$ & 3.92 & 1.71 \\
-150 & 2.13 & 0.39 \\
\hline
\end{tabular}


ROM Size Distribution

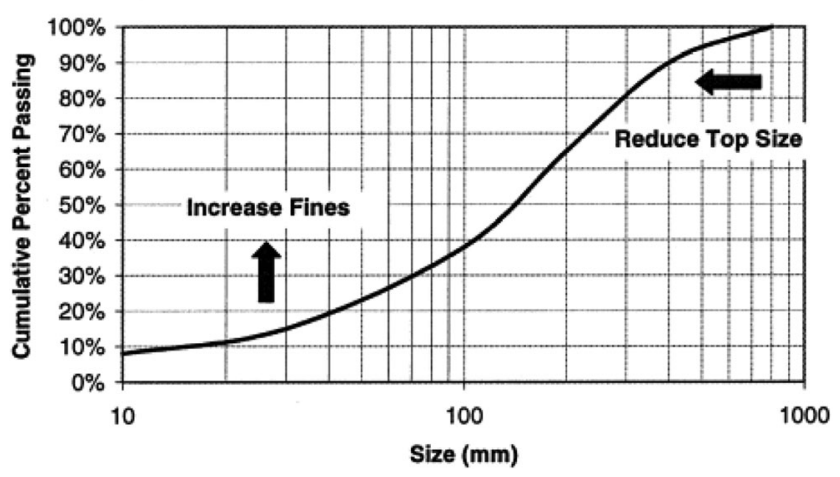

Fig. 4 Changes in size distribution sought through blasting [17]

ore, generated from a narrow section of reef and the second from selective blasting a small stope of the same reef.

Approximately $800 \mathrm{~kg}(2 \times 44$ gallon drums $)$ of thermally fragmented ore and $1500 \mathrm{~kg}(4 \times 44$ gallon drums $)$ of blasted ore samples were received, and representative samples were generated by cone and quartering for both ores.

\subsection{Methodology}

The particle size distributions of the thermal and blasted ores were generated by a measure of the retained masses on shaker screens following the generation of a representative sample of the ore.

For the thermal ore, due to its narrow size distribution, the total sample was coned and quartered in order to obtain a tentative size distribution. From this, the 95\% passing size was obtained and used to formulate the representative mass by means of Gy's sampling theory formula [20]:

$M=\frac{C d^{3}}{s^{2}}$

where $M$ is the minimum mass of sample, $\mathrm{g} ; d$ is the screen size that retains coarsest $5 \%$ of material, $\mathrm{P} 95 \mathrm{~cm} ; s$ is the statistical sampling error and $C$ is the sampling constant for the material sampled, $\frac{\mathrm{g}}{\mathrm{cm}^{3}}$

Once formulated, the mass was obtained by cone and quartering the recombined sample.
Due to the volume and broad size distribution of the blasted ore, generation of a tentative size distribution would prove difficult, and therefore the use of the Gy formula would not be feasible. Due to this, a size distribution was completed on the $1500 \mathrm{~kg}$ sample.

Gravity concentrates of five size fractions $(+9.5 \mathrm{~mm},-$ $9.5+2 \mathrm{~mm},-2 \mathrm{~mm}+1 \mathrm{~mm},-1000+300 \mu \mathrm{m}$ and -300 $\mu \mathrm{m})$ of both ores were assessed for the gold liberation. The degree of liberation on the $+9.5 \mathrm{~mm}$ material was visually analysed. The samples were wetted to increase reflectivity and manually inspected. Optical microscopy was used for testing gold liberation in samples $-9.5 \mathrm{~mm}$.

Each of the size fractions $(+9.5 \mathrm{~mm},-9.5+2 \mathrm{~mm}$ and $-2 \mathrm{~mm}$ ) of the thermal fragmentation and selected blasted samples were analysed for cyanide leachable gold content. Solid residue from the cyanide leachable test was analysed for gold by fire assay. The tests allow to determine the amount of gold leached by cyanide and total gold content of a sample.

\section{Results and Discussion}

\subsection{Sample Size Analysis}

Particle size distribution data generated for the thermally fragmented and blasted rock samples displayed the significant difference in breakage behaviour between the methods (Fig. 3). The blasted rock was shown to possess a broad spectrum of sizes, $54.9 \%$ of which was reported to the coarse size fraction. The thermal sample demonstrated a tendency for material to fragment in the -9.5 $+2 \mathrm{~mm}$ fraction (Table 4). The thermal process proved more proficient at generating fines, with an additional $15.9 \%$ reporting to the fine particle size fraction.

The results show that $23.96 \%$ and $12.50 \%$ of the total masses, for thermal and blasted products, respectively, reported to the $-4.75+2 \mathrm{~mm}$ screen (Table 5), representing the greatest accumulation of either product on a single screen. Thermal fragmentation resulted in 1.9 times the percentage of particles retained at this size, re-enforcing the understanding of the intergranular
Table 6 Extraction method comparison

\begin{tabular}{lll}
\hline Tonnage calculation (40 m by $20 \mathrm{~m}$, ore block) & Thermal fragmentation & Shrinkage stoping \\
\hline Width in situ $(\mathrm{m})$ & 0.5 & 0.5 \\
Mining width, final result $(\mathrm{m})$ & 0.5 & 1.8 \\
Dilution (\%) & 0 & 260 \\
Height $(\mathrm{m})$ & 20 & 20 \\
Length $(\mathrm{m})$ & 40 & 40 \\
Density $\left(\mathrm{kg} / \mathrm{m}^{3}\right)$ & 2800 & 2800 \\
Total mass $(\mathrm{t})$ & 1120 & 4032 \\
\hline
\end{tabular}


Table 7 Theoretical mass distribution

\begin{tabular}{llllll}
\hline Size fraction $(\mathrm{mm})$ & \multicolumn{2}{l}{ Thermal product } & & \multicolumn{2}{l}{ Blasted product } \\
\cline { 2 - 3 } & Retained $(\%)$ & Mass extracted $(1120 \mathrm{t})$ & & Retained $(\%)$ & Mass extracted (4032 t) \\
\hline+9.5 & 23.86 & 267.22 & 54.91 & 2213.81 \\
$-9.5+2$ & 41.00 & 109.57 & 25.89 & 573.25 \\
-2 & 35.14 & 38.50 & & 19.20 & 110.06 \\
\hline
\end{tabular}

fracture breakage mechanism attributed to differential thermal expansion due to thermal stress.

Thermal fragmentation achieves the two objectives stipulated by Scott, Kanchibotla \& Morrell; it reduced the top size of the material and increased the proportion of fines (Fig. 4). Their approach involved the optimisation of blasting practices at an increase in unit mining costs.

The size characteristics sought by blast optimisation in Fig. 4 are evident in the representation of the size distributions of the blasted and thermal products in Fig. 3. A reduction in the top size and an increase in the production of fines can be observed.

The influence of the selectivity and the product size characteristics of this process can be investigated in a rudimentary comparison of the costs associated with the extraction and initial comminution of a narrow vein of ore.

\subsection{Rudimentary Cost Comparison of Reduction Processes}

Using the method comparison by Donald and JeanPhillip Brisebois (Table 6), an estimate of the produced fragmented rock can be extrapolated using the tonnages produced in their method comparison and the retained mass fractions of the blasting and thermal processes.

This analysis assumes that the blasting and thermal breakage characteristics obtained during completed research will be consistent with those encountered, investigated in the presented comparison (Table 7).

Production reduction costs are evaluated for a primary cycle through a comminution circuit using the theoretical mass distribution and the reduction cost per tonne for crushing and grinding (Table 8) [18].

The comminution costs in Table 9 were generated with the supposition that the fragmented material above $2 \mathrm{~mm}$ would report to a crushing circuit costing $\$ 0.75 / \mathrm{t}$, and material passing $2 \mathrm{~mm}$ would report to grinding costing \$3.75/t.
This comparison shows that mining by means of thermal fragmentation is $82.9 \%$ less cost-intensive due to the reduction in sample size attributed to the selectivity of the process and the product particle size. Further comminution of the products would invariably result in additional savings due to the considerable difference in mined tonnes that would require crushing. This is due to the observed inefficiency of grinding relative to crushing, requiring 10 times the energy to grind the same volume of ore.

\subsection{Bond Work Index}

The Bond work index is used to calculate the grindability of ore and to postulate processing plant design. The Bond grindability test can be utilised to determine the difference in comminution energy requirements for traditionally blasted ore and thermally fragmented ore.

Comminution is an energy intensive process and represents relatively high operating cost and high capital expenditure. Thus, improvements in comminution performance is essential to support cost reduction, and estimation of the required energy assists to streamline the process of designing mining operations. Energy consumption models have been developed, including the Bond grindability test. First developed in the late 1920s by Fred Chester Bond, the Bond grindability test is the most well-known method and is used worldwide [13].

Both samples used in this test, thermally fragmented and blasted ore, were from the same mine site and are considered to be identical in terms of mineralogy and genesis. Therefore the method of extraction should be the only variable on the breakage characteristics of each ore type.

The grindability data, in conjunction with a number of equations formulated for the Bond work index calculation
Table 8 Reduction costs for crushing and grinding

\begin{tabular}{lllll}
\hline Comminution & Energy $(\mathrm{kWh} / \mathrm{t})$ & Energy multiplying factor & Cost $(\mathrm{AUD} / \mathrm{t})$ & Cost multiplying factor \\
\hline Crushing & 2 & 10 & 0.75 & 5 \\
Grinding & 20 & 100 & 3.75 & 25 \\
\hline
\end{tabular}


Table 9 Cost of primary comminution processing product of thermal fragmentation and selective blasting techniques.

\begin{tabular}{|c|c|c|c|c|}
\hline \multirow{2}{*}{$\begin{array}{l}\text { Size fraction } \\
(\mathrm{mm})\end{array}$} & \multicolumn{2}{|l|}{ Thermal product } & \multicolumn{2}{|l|}{ Blasted product } \\
\hline & $\begin{array}{l}\text { Theoretically retained } \\
\text { mass }(t)\end{array}$ & $\begin{array}{l}\text { Cost of reduction } \\
\text { (AUD) }\end{array}$ & $\begin{array}{l}\text { Theoretically retained } \\
\text { mass }(t)\end{array}$ & $\begin{array}{l}\text { Cost of reduction } \\
\text { (AUD) }\end{array}$ \\
\hline+9.5 & 267.22 & 200.42 & 2213.81 & 1660.36 \\
\hline$-9.5+2$ & 109.57 & 82.18 & 573.25 & 429.94 \\
\hline \multirow[t]{2}{*}{-2} & 38.50 & 144.38 & 110.06 & 412.73 \\
\hline & Total Cost (\$) & 426.97 & Total Cost (\$) & 2503.03 \\
\hline
\end{tabular}

enabled evaluation of values for Bond work index and actual energy input.

Bond work index:

Bond work index $\}$ Wi $\}\left(\frac{\mathrm{kWhr}}{\mathrm{t}}\right)=\frac{44.5}{\left[P_{\mathrm{i}}\right]^{0.28} \times\left[G_{80}\right]^{0.82}\left(\frac{10}{\sqrt{P_{80}}}-\frac{10}{\sqrt{F_{80}}}\right)}$

where $P_{\mathrm{i}}$ is the mesh of grind size, $\mu \mathrm{m}$ (106 $\mu \mathrm{m}$ used); $P_{80}$ is the $80 \%$ cumulative passing of product, $\mu \mathrm{m} ; F_{80}$ is the $80 \%$ cumulative passing of feed, $\mu \mathrm{m}$ and $G$ is the grindability, grammes per revolutions (gpr).

Bond work index testing supports the conclusion that the thermal stress applied to the rock during fragmentation and the subsequent quenching elicits a preconditioning effect on the ore. The obtained values for the product work index allow for the calculation for the energy input required to reduce the given samples.

Actual work:

Actual work input $\} \mathrm{W}\}\left(\frac{\mathrm{kWh}}{\mathrm{t}}\right)=\mathrm{Wi}\left(\frac{10}{\sqrt{P_{80}}}-\frac{10}{\sqrt{F_{80}}}\right)$

where $\mathrm{W}_{\mathrm{i}}$ is the Bond work index; $P_{80}$ is the $80 \%$ cumulative passing of product, $\mu \mathrm{m}$ and $F_{80}$ is the $80 \%$ cumulative passing of feed, $\mu \mathrm{m}$.

An example was formulated with relevance to the size distribution data, showing the actual work input required to reduce a tonne of each mining product from its respective $80 \%$ passing size to an $80 \%$ passing size of $2 \mathrm{~mm}$. Results (Tables 10 and 11) showed that reducing the blasted rock from $41 \mathrm{~mm}$ at its Bond work index of $25.32 \mathrm{kWh} / \mathrm{t}$ required 2.5 times more energy than reducing the thermal sample from $14 \mathrm{~mm}$. These findings also would influence the cost comparison completed previously ("Rudimentary Cost Comparison of

Table 10 Bond work index results summary

\begin{tabular}{lll}
\hline & Blasted ore & Thermal ore \\
\hline Bond work index $(\mathrm{kWh} / \mathrm{t})$ & 25.32 & 12.62 \\
Actual work $(\mathrm{kWh} / \mathrm{t})$ & 21.29 & 10.25 \\
\hline
\end{tabular}

Reduction Processes" section), significantly reducing the cost of comminution of thermal rock relative to that of an equal volume sample of blasted rock. An observation can be made from the average grindability values obtained from the Bond Index Test work (Table 12), that the average grindability obtained for the thermal ore sample was greater than the blasted sample by a factor of 2.44, a higher value indicating a decrease in the energy required to grind.

The Bond work index grindability tests were completed in a single time for each sample in order to obtain an understanding of the relative difference in the reduction energy requirements between the primary rock breakage methods. The evaluation of the Bond work index of a material is a comprehensive process, requiring multiple stages of grinding to obtain a mean grindability. Several grindability tests are often required to obtain a true representation of a material's Bond work index and because of this, the Bond index values obtained may be subjected to inconsistency due to the single grindability test evaluation of the Bond work index.

Test work was completed with the assumption of a relatively equivalent geological composition between the samples, and this hypothesis is encouraged by the identical size distribution characteristics of the samples grinded for the Bond work index feed. The size distribution profiles of the undersize material also endorse this supposition, indicating uniformity of breakage behaviour, independent of the method of extraction. This identical breakage behaviour can be attributed to the relatively equivalent geological composition between the samples. Unfortunately, consistent or uniform geological conditions are not a guarantee in mining, and this may also contribute to variance in Bond Work Index.

Table 11 Actual work example

\begin{tabular}{lll}
\hline Parameter & Blasted ore & Thermal ore \\
\hline Bond work index $(\mathrm{kWh} / \mathrm{t})$ & 25.32 & 12.62 \\
Actual work $(\mathrm{kWh} / \mathrm{t})$ & 4.41 & 1.75 \\
\hline
\end{tabular}


Table 12 Bond Index grindability values for material

\begin{tabular}{lll}
\hline & Thermal ore & Blasted ore \\
\hline Average grindability & 1.218 & 0.500 \\
\hline
\end{tabular}

\subsection{Gold Assays}

The results of the test work (Tables 13 and 14) show that coarse particle fraction $(+9.5 \mathrm{~mm})$ contains similar amount of gold, around $45 \%$, available for cyanide leach for both thermal and blasted sample. In size fraction $-9.5+2 \mathrm{~mm}$, dissolution increased up to $83 \%$ and $69 \%$ for the sample generated by thermal fragmentation and selective blasted sample, respectively. Therefore, $17 \%$ of gold of thermal sample and $31 \%$ of blasted material of this particle size range is not dissolved due to gold having no access to leachate. Even fines (- 2 $\mathrm{mm}$ ) demonstrate comparable gold leachability, $92 \%$ for thermal and $90 \%$ for blasted material, production of the fine material is $16 \%$ greater for the thermal fragmentation method.

The thermal fragmentation method generates product with higher dissolution of gold in cyanide, by $14 \%$ for $-9.5+2 \mathrm{~mm}$ size fraction. Additionally, the tests show higher production of $-9.5+2 \mathrm{~mm}$ material by the thermal fragmentation, $41 \%$, compared with selective blasting method of breakage, $25.9 \%$ (Table 4). It is reasonable to conclude that the thermal fragmentation breakage mechanism promotes breakage along adjacent grains of gold and gangue which increases access of the valuable to leachate and as result enhances dissolution of gold.

\subsection{Microscope Work}

Visual and optical microscopic examination of gravity concentrated samples, thermal and blasted, at $+9.5 \mathrm{~mm},-9.5+$ $2 \mathrm{~mm}$ and $-2 \mathrm{~mm}$ was performed.

There was no liberation of gold from the host rock identified in $+9.5 \mathrm{~mm}$ and $-9.5+2 \mathrm{~mm}$ size fractions of both samples, thermal fragmented and blasted sample. As can be seen from Fig. 5, visible gold is present with quartz in the size fraction of $-9.5+2 \mathrm{~mm}$.

Table 13 Thermal sample grade assay of cyanide leachable gold and fire assay of cyanide leach residue

\begin{tabular}{lll}
\hline Size fraction $(\mathrm{mm})$ & Cyanide leachable $\mathrm{Au}(\mathrm{g} / \mathrm{t})$ & Leach residue $\mathrm{Au}(\mathrm{g} / \mathrm{t})$ \\
\hline+9.5 & 0.115 & 0.14 \\
$-9.5+2$ & 1.285 & 0.27 \\
-2 & 2.045 & 0.185 \\
\hline
\end{tabular}

Table 14 Blasted sample assay data of cyanide leachable gold and fire assay of cyanide leach residue

\begin{tabular}{lll}
\hline Size fraction $(\mathrm{mm})$ & Cyanide leachable $\mathrm{Au}(\mathrm{g} / \mathrm{t})$ & Leach residue $\mathrm{Au}(\mathrm{g} / \mathrm{t})$ \\
\hline+9.5 & 0.185 & 0.215 \\
$-9.5+2$ & 0.415 & 0.19 \\
-2 & 2.33 & 0.25 \\
\hline
\end{tabular}

The samples analysed under the microscope showed significant liberation of gold below 300 micron. In the size range of $-1000+300$ micron, it appeared that liberation of gold was largely complete in the thermally fragmented sample, whereas in some cases the blasted rock gold particles still possessed gangue minerals. It was observed that a large degree of gold mineralisation was occurring in the host rock as opposed to the quartz, this could impact the mining width selected for extraction. No significant trend was observed concerning a tendency for one product to become liberated at a courser size than the other.

The only evidence for free gold particles was found in material less than $2 \mathrm{~mm}$ (Figs. 6, 7 and 8).

\section{Conclusions}

The current study indicates the different effects of the thermal fragmentation and selective blasting methods on the property of the product generated from the Australian hard rock underground narrow-vein mining. However, this study is very limited due to the number of samples and the fact that it is single site-specific. As such, it cannot be definitively stated that the results are representative of the Australian mining industry. Further work from other sites would be needed to prove the results from this study can be replicated across other mines and other mineral commodities.

For the study, undertaken investigation of the primary mining products from both methods show substantial financial benefit can be theoretically obtained due to the size and breakage characteristics of thermal process. Due to the increased selectivity of the thermal process, less tonnes need to be generated to mine a narrow width of ore, increasing the financial benefit of this method of extraction. Degree of liberation and availability of gold for dissolution findings are significant in influencing the applicability of this process.

Further research trials and analysis will serve to reinforce the benefits of this mining method.

Acknowledgements The authors would like to acknowledge the support provided by the Federation University, Australia, in the preparation and dissemination of this article to the mining community. 
Fig. 5 Gold present in quartz matrix, $-9.5+2 \mathrm{~mm}$ size fraction, thermal fragmented sample (left) and blasted rock sample (right)

Fig. 6 Liberated gold particles, $2+1 \mathrm{~mm}$ size fraction of thermal fragmented sample

Fig. 7 Liberated gold, $-1000+$ $300 \mu \mathrm{m}$ size fraction of thermal fragmented sample (left) and lasted sample (right)

Fig. 8 Liberated gold, $-300 \mu \mathrm{m}$ size fraction of thermal fragmented sample (left) and blasted sample (right)
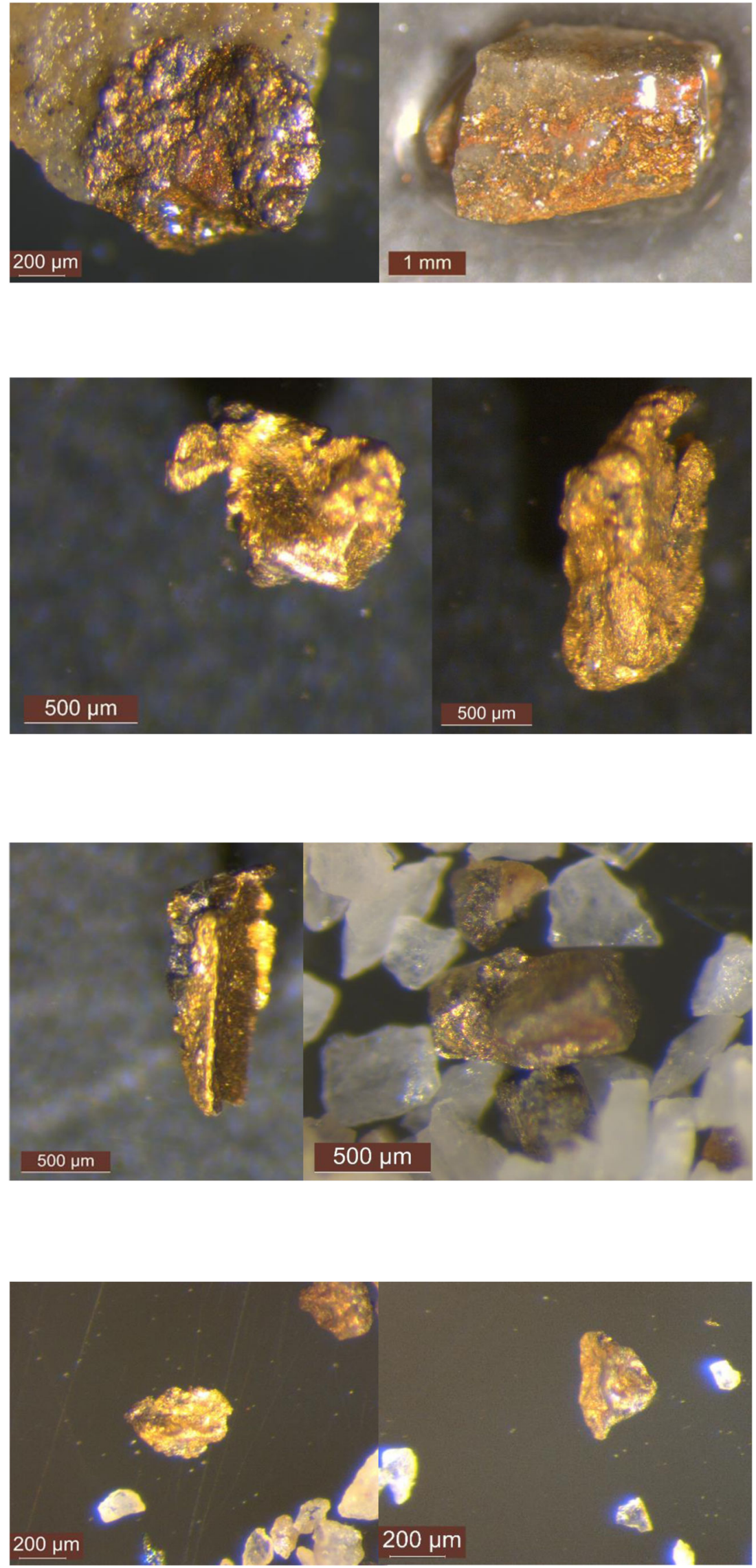


\section{Compliance with Ethical Standards}

Conflict of Interest The authors declare that they have no conflict of interest.

\section{References}

1. Brisebois D (2016a) About us - corportate presentation. Retrieved from Nippon Dragon Resources: http://www.nippondragon.com/ images/PDF-Documents/Corporate\%20Presentation\%20Nippon\% 20Dragon\%20Resources.pdf

2. Brisebois D (2016b) Change mining mindset. Nippon Dragon Resources Inc., Quebec

3. Brisebois D (2016c) RE: Pictures thermal

4. Brisebois D, Brisebois J-P (n.d.) Thermal fragmentation: reducing mining width when extracting narrow precious metal veins. Quebec, Canada

5. Brown J, Gaudin A (1960) Mechanism of intergranual comminution by heading. Massachusetts Institute of Technology, Cambridge

6. Brown J, Gaudin A, Loeb C Jr (1958) Intergranular comminution by heating. Mining Engineering 211:490-496

7. Dominy S, Phelps R, Sangster CA (1998) Narrow vein mining techniques in the United Kingdom. Underground Operators' Conference, (pp. 227-237). Townsville

8. Dominy S, Annels A, Barr S, Hodkinson IA (1999) Gold grade distribution and estimation in narrow vein systems. PACRIM ' 99. Bali, pp 411-425

9. Fecteau J, Poirier SA (2001) Narrow-vein mining project: a special initiative of natural resources Canada. 6th International Symposium on Mine Mechanization. pp 11-16
10. Herbst JA (2000) Mine-to-mill optimisation - research and practice. University of Utah, Department of Metallurgy, Melbourne

11. Kenyen VP (1984) Million dollar grinding mill - is it for you? Mining Engineering 1984:1422-1426

12. Larsen P, Richard CA (1990) Application of longhole drilling methods for narrow vein mining. CIM Bulletin:35-40

13. Lynch A (2015) Comminution. The Australian Institute of Mining and Metallurgy, Melbourne

14. McCarthy P (1993) Economics of narrow vein mining. Narrow Vein Mining Seminar. Bendigo, Victoria, pp 89-98

15. Poirier S, Fecteau J-M, Brisebois D (2002) Thermal rock fragmentation applications in narrow-vein extraction. Vancouver

16. Powell M (2013). Infographic - counting the cost of comminution. Retrieved October 8, 2016, from mining-technology.com: http:// www.mining-technology.comfeaturesfeaturecomminution-energycosts-mining-industry-savings

17. Scott A, Kanchibotla S, Morrel S (1999) Blasting for mine to mill optimisation. Kalgoorlie, WA

18. Scott A, Segui J, Kanchibotla S (2000) Ore characteristics for mine to mill fragmentation. 4th International Mining Geology Conference. Coolum, QLD, pp 247-253

19. Tavares L, King R (1995) Application of thermal treatment to improve comminution. Denver, Colorado

20. Wills BA, Napier-Munn T (2006) Mineral processing technology, 7th edn. Elsevier Science \& Technology Books, Brisbane

21. Zeng Y (1992) Energy consumption in fine crushing and dry rod grinding. SME nonmeeting paper 91-657, pp 69-72

Publisher's Note Springer Nature remains neutral with regard to jurisdictional claims in published maps and institutional affiliations. 